\title{
Antibacterial, haematological parameters and phytochemical analysis of the leaf extracts of Moringa oleifera
}

\begin{abstract}
Antimicrobial resistance has become a global problem and Strategies to improve the current situation necessitate finding new and innovative antimicrobial agents. Forty apparently healthy albino mice of either sex, weighing between $19 \mathrm{~kg}$ and $27 \mathrm{~kg}$, aged 2 to 3 weeks were purchased and the various concentration of the extracts from Moringa oleifera leaves were given orally to the mice, the highest mean PCV was recorded in $800 \mathrm{mg}$ (33.0 1.22 ), White blood cell count $400 \mathrm{mg}$ (3,725 \pm 923.20$)$, Neutrophil count $100 \mathrm{mg}(24.8 \pm 7 \pm .65)$ and lymphocytes count $400 \mathrm{mg}(87.5 \pm 1.85)$, ethanol extracts

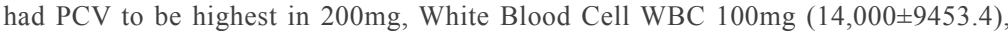
neutrophils count $400 \mathrm{mg}(12.8 \pm 2.02)$ and lymphocytes count $800 \mathrm{mg}(91.5 \pm 2.22)$, the antimicrobial activity of the extracts on clinical isolates showed that the water extract $800 \mathrm{mg} / \mathrm{ml}$ had the highest zone of inhibition of $6 \mathrm{~mm}$ on the Escherichia coli, $19 \mathrm{~mm}$ against Staphylococcus aureus, $18 \mathrm{~mm}$ against Proteus mirabilis and $14 \mathrm{~mm}$ against Escherichia coli, the ethanol extracts $800 \mathrm{mg} / \mathrm{ml}$ had the highest zone of inhibition of $8 \mathrm{~mm}$ against Salmonella typhii. $6 \mathrm{~mm}$ against E.coli and S.aureus and $5 \mathrm{~mm}$ against P.mirabilis, The phytochemical screening showed that both water and ethanol extracts had Flavonoid, Tannin, Glycoside, Terpenoid and Saponin with the absence of alkaloids in water, while reducing sugar was absent in both with Terpenoid having the highest concentrations in ethanol extracts $12.95 \mathrm{mg} / \mathrm{g}$ and water extracts $10.30 \mathrm{mg} / \mathrm{g}$.
\end{abstract}

Keywords: antibacterial, haematological parameters, phytochemical, Moringa oleifera
Volume 3 Issue 3 - 2016

\author{
Olaniran O,' Adetuyi FC, ${ }^{2}$ Omoya FO, ${ }^{2}$ \\ Odediran SA, ${ }^{4}$ Hassan-olajokun RE,' \\ Awoyeni EA,' Odetoyin BW,' Akinyemi LO, ${ }^{5}$ \\ Oyetoke $0,{ }^{6}$ Afolayan $\mathrm{DO}^{7}$ \\ 'Department of Medical Microbiology and Parasitology Obafemi, \\ Awolowo University lle-lfe, Nigeria \\ ${ }^{2,3}$ Department of Microbiology, Federal University of Technology \\ Akure, Nigeria \\ ${ }^{4}$ Department of Pharmacognosy, Faculty of Pharmacy, Obafemi \\ Awolowo University lle-Ife, Nigeria \\ ${ }^{5}$ Department of Hematology and Immunology, College of Health \\ Sciences Obafemi Awolowo University lle-Ife, Nigeria \\ ${ }^{6}$ Department of Medical Microbiology and Parasitology Obafemi \\ Awolowo University Teaching Hospital Complex lle-lfe, Nigeria \\ Multidisciplinary Laboratory, Obafemi Awolowo University \\ lle-Ife, Nigeria
}

Correspondence: Olaniran Olarinde, Department of Medical Microbiology and Parasitology O.A.U lle-lfe,

Email olarinde7I@gmail.com

Received: July 27, 2016 | Published: December 28, 2016

\section{Introduction}

Antibacterial resistance has become a global problem and Strategies to improve the current situation necessitate finding new and innovative antibacterial (antibiotics) though the chemotherapeutic agents have been of value in controlling many infections but they require on judicious use in order to minimize the incidence of resistant. Approximately $20 \%$ of the plants are sources of a substantial number of natural or semi-synthetic antibiotics in the market. In developing countries, due to the cost of large proportion of the population utilize medicinal plants for the treatment of infectious diseases and much research has been done worldwide to identify and study antibacterial compounds found in medicinal plants. According to Fahey. ${ }^{1}$

Increased vegetable utilization and consumption are critical to alleviate world-wide incidence of nutritional deficiencies. Our survey and investigations on some plants indicated that Moringa oleifera is one of the promising plants which could contribute to increased intake of some essential nutrients and health-promoting phytochemicals. Phytochemicals are present in virtually all of the fruits, vegetables, legumes (beans and peas), and grains we eat, so it is quite easy for most people to include them in their diet. Moringa oleifera, or the horseradish tree, is a pan-tropical species that is known by such regional names as benzolive, drumstick tree, kelor, marango, saijhan, and sajna. ${ }^{1}$ It is considered one of the world's most useful trees, as almost every part of the tree can be used for food, or has some other beneficial properties. The leaves, especially young shoots, are eaten as greens, in salads, in vegetable curries, and as pickles. The leaves can be eaten fresh, cooked, or stored as dried powder for many months without refrigeration, and reportedly without loss of nutritional value. The leaves are considered to offer great potential for those who are nutritionally at risk and may be regarded as a protein and calcium supplement (Rajangam et al. 2001). The Specific Objectives of this research are to: determine the antibacterial activity of the leaf extract of Moringa oleifera against selected medically important bacteria, evaluate the phytochemicals present in the leaf extract and the heamatological parameters of the leaf extracts in mice.

\section{Materials and methods}

\section{Plant collection and extract preparation}

The leave stalks of Moringa oleifera were collected from IleIfe, Osun State. Nigeria and identity confirmed in the department of Botany, Obafemi Awolowo University. Physical selection of the apparently healthy leaves was carried out and the selected leaves were air dried and pounded into a coarse powder using laboratory pestle and mortar. To $50 \mathrm{~g}$ of the leaf powder was added $300 \mathrm{mls}$ of distilled water and ethanol respectively and was thoroughly mixed and allowed to stand for one hour before filtering with the aid of whatman filter paper number 1. The filtrates were taken to the Faculty of Pharmacy, Obafemi Awolowo University in order to get the concentrate of the leave extracts which was administered to the mice and used for the antibacterial activity. 


\section{Experimental animal}

Forty apparently healthy albino mice of either sex, weighing between $19 \mathrm{~kg}$ and $27 \mathrm{~kg}$, aged 2 to 3 weeks were purchased from the animal house of the College of Health Sciences Obafemi Awolowo University Ile-Ife. Nigeria. The animals were allowed to acclimatize for one week. The mice were divided into six groups of four mice each, groups 1 and II serve as negative and positive control respectively, while III to VI were for test doses of $100 \mathrm{mg}, 200 \mathrm{mg}, 400 \mathrm{mg}$ and $800 \mathrm{mg} / \mathrm{kg}$ body weight.

\section{Determination of hematological parameters of the mice}

Counting White cells: 0.381 of diluting fluid (Turk's solution) was measured and dispensed into a small tube. $0.02 \mathrm{ml}$ of well-mixed EDTA anti coagulated venous blood from mice was added and mixed. The counting chamber was assembled and the diluted blood sample using a capillary tube held at an angle of about 45 was used to fill one of the grids of the chamber with the sample taking care not to over fill the area. The chamber was left undisturbed for 2 minutes to allow time for the white cells to settle. The underside of the chamber was wiped dried and place it on the microscope stage and using the X10 objective with the condenser iris closed sufficiently to give good contrast, the cells was focused until they appear as small black dots. The cells in the four large corner squares of the chamber were counted including the cells lying on the lines of two sides of each large square. The readings were done.

Differential white cell count: To a well made and correctly stained thin blood film, a drop of immersion oil was dropped on the lower third of the blood film and cover with a clean cover glass. The film was examined microscopically using X10 objective with the condenser iris closed sufficiently to see the cells clearly and to view the part of the film where the red cells are just beginning to overlap and the $\mathrm{x}$ 40objective was used to focus the blood film. The blood film was systematically examined and different white cell was counted as seen in each field using an automatic differential cell counter.

Estimation of Packed cell volume (PCV): The blood from the tail of the animals was drawn and duplicate determinations were done by measuring the relative volume of the blood occupied by erythrocytes in Microhaematocrit tube by using the relation:

$$
\mathrm{PCV}=\frac{\text { Length of red cell column }(\mathrm{mm})}{\text { Length of total column }(\mathrm{mm})} \times 100
$$

\section{Microbiological analysis}

Extracts preparation: Extract concentrations were prepared by dissolving known weight of the concentration of crude aqueous and ethanol extracts in known volume of distilled water to give $100 \mathrm{mg} /$ $\mathrm{ml}, 200 \mathrm{mg} / \mathrm{ml}, 400 \mathrm{mg} / \mathrm{ml}$ and $800 \mathrm{mg} / \mathrm{ml}$ of the crude extract. $250 \mathrm{mg} /$ $\mathrm{ml}$ of the standard antibacterial agent (tetracycline) was similarly constituted.

Microorganisms: The organisms used were Escherichia coli, Pseudomonas aeroginosa, Staphylococcus aureus, Klebsiella aerogenes, Proteus mirabilis and Salmonella typhi. The organisms were obtained from the Department of Medical Microbiology and Parasitology Laboratory, Obafemi Awolowo University Teaching Hospital Complex Ile-Ife Osun State and reconfirmed by performing biochemical test such as sugar fermentation, citrate, oxidase, urease tests, and production of hydrogen sulphide, gas, and motility on the organisms.

Determination of antibacterial activity: The antibacterial activity of the leaf extracts was determined using agar well diffusion method by following the known procedure. Diagnostic sensitivity Test Agar (DST) was inoculated with the given microorganisms by spreading the bacterial inoculums (compared with MacFaland standard) on the media. Wells were punched in the agar and filled with different concentrations of the plant extracts. Control wells containing neat solvents (negative control) were also run parallel in the same plate. The plates were incubated at $37^{\circ} \mathrm{C}$ for 18 hours and the antibacterial activity was assessed by measuring the diameter of the zone of inhibition. The antibacterial potential of the different extracts was evaluated by comparing their zones of inhibition.

Phytochemical evaluation: The extracts were analyzed by the following procedures to test for the presence of the alkaloids, saponins, tannins, Terpenoids, flavonoids, glycosides, volatile oils and reducing sugars.

Saponins: Saponins were detected using the froth test. $1 \mathrm{~g}$ of the sample was weighed into a conical flask in which $10 \mathrm{ml}$ of sterile distilled water was added and boiled for 5 minutes. The mixture was filtered and $2.5 \mathrm{ml}$ of the filtrate was added to $10 \mathrm{ml}$ of sterile distilled water in a test tube. The test tube was stoppered and shaken vigorously for about 30 seconds. It was then allowed to stand for half an hour. Honeycomb froth indicated the presence of saponins. ${ }^{2}$

Tannins: To a portion of the extract diluted with water, 3-4 drops of $10 \%$ ferric chloride solution is added. A blue color is observed for Gallic tannins and green color indicates for catecholic tannins. ${ }^{3}$

Reducing Sugars: To $0.5 \mathrm{ml}$ of plant extracts, $1 \mathrm{ml}$ of water and $5-8$ drops of Fehling's solution was added and heated over water bath. Brick red precipitate indicates the presence of reducing sugars. ${ }^{3}$

Glycosides: $25 \mathrm{ml}$ of dilute sulphuric acid was added to $5 \mathrm{ml}$ extract in a test tube and boiled for 15 minutes, cooled and neutralized with $10 \%$ $\mathrm{NaOH}$, then $5 \mathrm{ml}$ of Fehling solution added. Glycosides are indicated by a brick red precipitate.

Alkaloids: $2 \mathrm{ml}$ of extract was measured in a test tube to which picric acid solution was added. An orange coloration indicated the presence of alkaloids.

Flavonoids: $4 \mathrm{ml}$ of extract solution was treated with $1.5 \mathrm{ml}$ of $50 \%$ methanol solution. The solution was warmed and metal magnesium was added. To this solution, 5-6 drops of concentrated hydrochloric acid was added and red color was observed for flavonoids and orange color for flavones. ${ }^{2}$

Volatile oils: $2 \mathrm{ml}$ of extract was shaken with $0.1 \mathrm{ml}$ dilute $\mathrm{NaOH}$ and a small quantity of dilute $\mathrm{HCl}$. A white precipitate is formed if volatile oils are present.

Terpenoids: Four milligrams of extract was treated with $0.5 \mathrm{ml}$ of acetic anhydride and $0.5 \mathrm{ml}$ of chloroform. Then concentrated solution of sulphuric acid was added slowly and red violet color was observed for terpenoids. ${ }^{4}$ 


\section{Results}

The profile of Haematological parameter such as packed cell volume (PCV), White blood cell count (WBC), Neutrophil and Lymphocyte counts on both ethanol and water extracts on M. oleifera. Packed cell volume (PCV) for negative control in water extract had mean PCV of $30.8 \pm 3.04$ while $800 \mathrm{mg}$ had $(33.0 \pm 1.22), 400 \mathrm{mg}$ had (32.8 \pm 1.32 ), and $200 \mathrm{mg}$ and $100 \mathrm{mg}$ had $32.3 \pm 3.22$ and $32.3 \pm 0.48$ respectively. The negative control for the $\mathrm{WBC}$ had mean value of $5,950 \pm 670.20$ while. The highest White blood cell count among the doses was recorded in $400 \mathrm{mg}(3,725 \pm 923.20)$ while the least was found in $200 \mathrm{mg}(3150 \pm 262.00)$. The negative control had mean Neutrophil count of $37.6 \pm 7.66$ while, the highest Neutrophil count was recorded in dose $100 \mathrm{mg}(24.8 \pm 7 \pm .65)$ followed by $800 \mathrm{mg}(22.3 \pm 1.75)$ and the least $400 \mathrm{mg}(13.8 \pm 1.70)$. The lymphocytes count in negative control was $59.3 \pm 7.76$ while the highest Lymphocytes count was found in $400 \mathrm{mg}(87.5 \pm 1.85)$ and the least was found with the dose $100 \mathrm{mg}(72.3 \pm 7.63)$. The ethanol extracts had PCV to be higher in $200 \mathrm{mg}(43.25 \pm 1.44)$ followed by $400 \mathrm{mg}(39.0 \pm 2.80)$, $800 \mathrm{mg}(35.75 \pm 4.66)$ and the least $100 \mathrm{mg}(24.75 \pm 3.82)$., the WBC was higher in $100 \mathrm{mg}(14,000 \pm 9453.4)$, followed by $200 \mathrm{mg}(6150 \pm 556.03)$ and the least is $400 \mathrm{mg}(3,150 \pm 550.00) .400 \mathrm{mg}$ had the highest neutrophils count, $400 \mathrm{mg}(12.8 \pm 2.02)$, followed $100 \mathrm{mg}(11.3 \pm 6.09)$ and the least $200 \mathrm{mg}(10.8 \pm 1.55)$. The lymphocytes count was higher in $800 \mathrm{mg}(91.5 \pm 2.22)$ followed by $400 \mathrm{mg}(88.8 \pm 2.02)$ and $100 \mathrm{mg}(88.8 \pm 6.09)$ and the least $200 \mathrm{mg}(88.3 \pm 1.49)$ (Table $1 \&$ Table 2).

\section{The antimicrobial activity of the Moringa oleifera leaf extract on some clinical isolates}

The antimicrobial activity of the extracts on clinical isolates showed that the water extract $800 \mathrm{mg}$ had the highest zone of inhibition of $6 \mathrm{~mm}$ on the Escherichia coli. Followed by $400 \mathrm{mg}$ with $4 \mathrm{~mm}$ zone of inhibition and the least $100 \mathrm{mg}$ with $2 \mathrm{~mm}$ zone of inhibition. As compared with the standard antibiotic Tetracycline 250mg having the highest zone of $21 \mathrm{~mm}$ against Klebsiella aerogenes, $19 \mathrm{~mm}$ against Staphylococcus aureus, $18 \mathrm{~mm}$ against Proteus mirabilis and 14 against Escherichia coli. The ethanol extracts $800 \mathrm{mg}$ had the highest zone of inhibition of $8 \mathrm{~mm}$ against Salmonella typhii, $6 \mathrm{~mm}$ against $E$. coli and $S$. aureus and $5 \mathrm{~mm}$ against $P$. mirabilis (Table $3 \&$ Table 4 ).

\section{The phytochemical screening of both ethanol and water extracts of M. Oleifera leaves}

The phytochemical screening showed that both water and ethanol extracts had Flavonoid, Tannin, Glycoside, Terpenoid, Saponin was absence in ethanol while alkaloids was absent in water. Reducing sugar was absent in both has shown in Table 5 .

Table I Profile of the packed cell volume, white blood cell, neutrophil and lymphocyte counts of the water extract of moringa oleifera leaves in mice (water extract)

\begin{tabular}{lllll}
\hline Drug group & PCV \pm SEM & WBC \pm SEM & NEUT \pm SEM & LYMPH \pm SEM \\
\hline Control(0.22ml) & $30.8 \pm 3.04$ & $5,950 \pm 670.20$ & $37.6 \pm 7.66$ & $59.3 \pm 7.76$ \\
Extract(100mg) & $32.3 \pm 0.48$ & $3,325 \pm 492.23$ & $24.8 \pm 7.63$ & $72.3 \pm 7.63$ \\
Extract(200mg) & $32.3 \pm 3.22$ & $3,150 \pm 262.00$ & $15.8 \pm 2.17$ & $83.8 \pm 2.25$ \\
Extract(400mg) & $32.8 \pm 1.32$ & $3,725 \pm 923.20$ & $13.8 \pm 1.70$ & $87.5 \pm 1.85$ \\
Extract(800mg) & $33.0 \pm 1.22$ & $3,675 \pm 975.85$ & $22.3 \pm 1.75$ & $74.3 \pm 1.70$
\end{tabular}

Keywords: PCV, packed cell volume;WBC, white blood cell count; NEUT, neutrophil count; LYMP, lymphocyte count

Table 2 Profile the packed cell volume, white blood cell, neutrophil and lymphocyte counts of the ethanol extract of moringa oleifera leaves in mice (ethanol extract)

\begin{tabular}{lcccc}
\hline Drug group & PCV \pm SEM & WBC \pm SEM & NEUT \pm SEM & LYMPH \pm SEM \\
\hline Control(0.22ml) & $30.8 \pm 3.04$ & $5,950 \pm 670.20$ & $37.6 \pm 7.66$ & $59.3 \pm 7.76$ \\
Extract(100mg) & $24.75 \pm 3.82$ & $14,000 \pm 9453.4$ & $11.3 \pm 6.09$ & $88.8 \pm 6.09$ \\
Extract(200mg) & $43.25 \pm 1.44$ & $6,150 \pm 556.03$ & $10.8 \pm 1.55$ & $88.3 \pm 1.49$ \\
Extract(400mg) & $39.0 \pm 2.80$ & $3,150 \pm 550.00$ & $12.8 \pm 2.02$ & $88.8 \pm 2.02$ \\
Extract(800mg) & $35.75 \pm 4.66$ & $5,600 \pm 844.59$ & $8.5 \pm 2.220$ & $91.5 \pm 2.22$
\end{tabular}

Keywords: PCV, packed cell volume;WBC, white blood cell count; NEUT, neutrophil count; LYMP, lymphocyte count 
Table 3 Antibacterial activities of the Moringa oleifera water leave extracts on some clinical isolates

\begin{tabular}{lllllll}
\hline & \multicolumn{5}{c}{ Extract doses $(\mathbf{m g})$} \\
\cline { 2 - 7 } Organisms & $\mathbf{5 0} \mathbf{m g} / \mathbf{m l}$ & $\mathbf{1 0 0} \mathbf{m g} / \mathbf{m l}$ & $\mathbf{2 0 0} \mathbf{m g} / \mathbf{m l}$ & $\mathbf{4 0 0} \mathbf{m g} / \mathbf{m l}$ & $\mathbf{8 0 0} \mathbf{m g} / \mathbf{m l}$ & Tet $(\mathbf{2 5 0} \mathbf{m g} / \mathbf{m l})$ \\
\hline S. aureus & $\mathrm{R}$ & $\mathrm{R}$ & $\mathrm{R}$ & $\mathrm{R}$ & $\mathrm{R}$ & $19 \mathrm{~mm}$ \\
K. aerogenes & $\mathrm{R}$ & $\mathrm{R}$ & $\mathrm{R}$ & $\mathrm{R}$ & $\mathrm{R}$ & $21 \mathrm{~mm}$ \\
E. coli & $\mathrm{R}$ & $\mathrm{R}$ & $2 \mathrm{~mm}$ & $4 \mathrm{~mm}$ & $6 \mathrm{~mm}$ & $14 \mathrm{~mm}$ \\
P. mirabilis & $\mathrm{R}$ & $\mathrm{R}$ & $\mathrm{R}$ & $\mathrm{R}$ & $\mathrm{R}$ & $18 \mathrm{~mm}$ \\
S. typhii & $\mathrm{R}$ & $\mathrm{R}$ & $\mathrm{R}$ & $\mathrm{R}$ & $\mathrm{R}$ & $13 \mathrm{~mm}$ \\
\hline
\end{tabular}

Keywords: S. aureus, staphylococcus aureus; P. mirabilis, proteus mirabilis; K. aerogenes, klesiella aerogenes; $\mathrm{S}$. typhi, salmonella typhii; E. coli, escherichia coli; R, resistance; Tet, tetracycline

Table 4 Antibacterial activities of the Moringa oleifera ethanol leave extracts on some clinical isolates

\begin{tabular}{lllllll}
\hline Ethanol extract & $\mathbf{5 0} \mathbf{m g} / \mathbf{m l}$ & $\mathbf{l 0 0} \mathbf{m g} / \mathbf{m l}$ & $\mathbf{2 0 0} \mathbf{m g} / \mathbf{m l}$ & $\mathbf{4 0 0} \mathbf{m g} / \mathbf{m l}$ & $\mathbf{8 0 0} \mathbf{m g} / \mathbf{m l}$ & Tet (250 \\
\hline S. aureus & $\mathrm{R}$ & $\mathrm{R}$ & $\mathrm{R}$ & $4 \mathrm{~mm}$ & $6 \mathrm{~mm}$ & $19 \mathrm{~mm}$ \\
K. arogenes & $\mathrm{R}$ & $\mathrm{R}$ & $\mathrm{R}$ & $\mathrm{R}$ & $\mathrm{R}$ & $21 \mathrm{~mm}$ \\
E. coli & $\mathrm{R}$ & $\mathrm{R}$ & $3 \mathrm{~mm}$ & $5 \mathrm{~mm}$ & $6 \mathrm{~mm}$ & $14 \mathrm{~mm}$ \\
P.mirabilis & $\mathrm{R}$ & $\mathrm{R}$ & $2 \mathrm{~mm}$ & $4 \mathrm{~mm}$ & $5 \mathrm{~mm}$ & $18 \mathrm{~mm}$ \\
S. typhii & $\mathrm{R}$ & $\mathrm{R}$ & $4 \mathrm{~mm}$ & $6 \mathrm{~mm}$ & $8 \mathrm{~mm}$ & $13 \mathrm{~mm}$
\end{tabular}

Keywords: S. aureus, staphylococcus aureus; P. mirabilis, proteus mirabilis; K. aerogenes, klesiella aerogenes; S. typhi, salmonella typhii; E. coli, escherichia coli; R, resistance; Tet, tetracycline

Table 5 Phytochemical analysis of Moringa oleifera leaves

\begin{tabular}{lll}
\hline Compounds & Water extracts $(\mathbf{m g} / \mathbf{g})$ & Ethanol extracts $(\mathbf{m g} / \mathbf{g})$ \\
\hline Tannins & $+(8.4 I)$ & $+(9.83)$ \\
Saponins & $+(0.40)$ & - \\
Glycosides & $+(6.09)$ & $+(7.85)$ \\
Reducing sugars & - & - \\
Terpenoids & $+(10 . .30)$ & $+(12.95)$ \\
Flavonoids & $+(6 . .57)$ & $+(9.41)$ \\
Alkanoids & - & $+(0.34)$ \\
\hline
\end{tabular}

$(++)$ - Moderate abundance of compound.

$(+)$ - Low abundance of compound.

(-) - Absent

\section{Discussion}

Both extracts demonstrated sensitivity to some of the microorganisms tested in a dose - dependent manner but were not as active as the positive control. Both were resistant to the entire organism at doses below $200 \mathrm{mg} / \mathrm{kg}$. Data from the ethanol was more sensitive at $200 \mathrm{mg} / \mathrm{kg}$ and above than the aqueous extract as the aqueous was only sensitive to $E$. coli above this dose while $K$. aerogenes was resistant at all doses to the ethanol extract which is in agreement with the work done by Abalaka et al. ${ }^{5}$ and Karthic et al. ${ }^{6}$ where crude extracts shows a remarkable activity against the growth of $E$. coli, Salmonella and Pseudomonas.. The aqueous extract was resistant to all the organisms tested except $E$. coli. Table 3 . Within the sensitivity span of the ethanol extract, S. typhi elicited the highest zone of inhibition (ZI) of $8 \mathrm{~mm}$ at the highest dose followed by $S$. aureus and $E$. coli at $6 \mathrm{~mm}$ but $S$. aureus was resistant at $200 \mathrm{mg}$ compared to $E$ coli $\mathrm{ZI}$ of $3 \mathrm{~mm}$ at the same dose. P. mirabilis had the lowest ZI at the highest dose tested; this also corroborated Vinoth ${ }^{4}$ data in which the ethanol extract was active against $S$. typhi and $S$. aureus. The result indicates that there was a significant increase in haematological indices, suggesting that Moringa oleifera is useful in immune activation in these mice.

The results of the phytochemical analyses showed that terpenoids were more elicited in quantity than the other phytochemicals tested. Terpenoids shows promise as an antioxidant. Its pungent scent is also added to fragrances, used in aromatherapy and as an expectorant, the chemical in eucalyptus stimulates the secretion of mucus. The oil might produce a diuretic effect, and can be taken orally to ease gastrointestinal spasms by increasing gastric juices in the gut. Tannins have being effective ameliorative agent in the kidney. ${ }^{7}$ Tannins have been shown to be a potential anti-viral, anti-bacterial and anti-parasitic agent. ${ }^{8}$ Flavonoids, which according to ${ }^{9}$ may modify allergens including 
viruses and carcinogens thereby acting like a biological response modifier. In addition, in vitro studies, ${ }^{10}$ showed that flavonoids could be anti-allergic (Spencer, 2008) and anti-inflammatory properties. ${ }^{11}$ Alkaloids are also known to have pharmacological effects and are also used as local anesthetic and stimulants. Cocaine, caffeine, nicotine, the analgesic morphine, the anti-bacterial berberine and antimalarial drug quinine are all Alkaloids. ${ }^{12}$ Saponins however are used as adjuvants in the production of vaccines. ${ }^{13}$

\section{Conclusion and recommendation}

From the study it can be concluded that Moringa oleifera leaves has antibacterial effect. Both extracts indicate there was a significant increase in haematological indices, suggesting that Moringa oleifera is useful in immune activation in these mice. According to the result from the study the following recommendation is given: due to the large scale consumption of this plant in Africa and the protective roles, more toxicological study especially in the use of special stains to study the detail of the toxicological effect should be embarked on so as to ascertain the safety.

\section{Acknowledgements}

None.

\section{Conflict of interest}

The author declares no conflict of interest.

\section{References}

1. Fahey JW. Moringa oleifera: A Review of the medical evidence for its nutritional, therapeutic, and prophylactic properties. Part 1. Trees for Life Journal. 2005;1:5
2. Sofowora EA. Medicinal Plants and Traditional Medicine in African Chichester, London: John Willey and Sons; 1982. p. 109-111.

3. Trease GE, Evans MD. A Textbook of Pharmacognosy. 13th ed. London: Builler Tindall and Caussel; 1989. p. 176-180.

4. Vinoth B, Manivasagaperumal R, Balamurugan S. Phytochemical analysis and antibacterial activity of Moringa oleifera. Int J Pharm Bio Sci. 2012;2(3):98-102.

5. Abalaka ME, Daniyan DY, Oyeleke SB, et al. The antibacterial evaluation of Moringa oleifera leaf extracts on selected Bacterial pathogen. Journal of Microbiology Research. 2012;2(2):1-4.

6. Karthic R, Singaram SS. In vitro antimicrobial activity and invivo toxicity of Moringa oleifera and Allamanda cathartica against multiple drug resistant clinical pathogens. Int J Pharm Bio Sci. 2013;4(1):768-778.

7. Bajaj YP. Medicinal and aromatic plants. Biotechnology in Agriculture and Forestry. Berlin; 1998. p. 24-25.

8. Lu L, Liu S, Jiang S, et al. Tannin inhibit Hiv-1 entry by targeting gp41. Acta Pharmacol Sin. 2004;25(2):213-218.

9. Mobh S. Research for Vitamin. The Journal of Biotechnology. 1938;4:2-6.

10. Galeotti F, Barile E, Curir P, et al. Flavonoids from carnation of Dianthus caryophyllus and antifugal activity. Phytochemistry letter. 2008;1(1):4460.

11. Yamamato G, Gaynor F. The therapeutic potential of inhibition of NF$\mathrm{Kb}$ pathway in the treatment of inflammation and cancer. J Clin Invest. 2000;107(2):135-142.

12. Mobh S. Research for Vitamin. The Journal of Biotechnology. 1938;4:2-6.

13. Asl M, Hossein H. Review of Pharmacological effects of Glycyrrhiza specie and its bioactive compounds. Phytother Res. 2008;22(66):709-724. 